\title{
Geotourism Potential as Information for Infrastructure Planning of the Karst Area, Kayen District, Pati Regency, Central Java
}

\author{
Tri Winarno ${ }^{1 *}$, Jenian Marin ${ }^{1}$, Rinal Khaidar $\mathrm{Ali}^{1}$, and Yudantoko Aditya Widianto ${ }^{1}$ \\ ${ }^{1}$ Department of Geological Engineering, Faculty of Engineering, Diponegoro University, Semarang - Indonesia
}

\begin{abstract}
Kayen District, Pati Regency is a karst morphology area composed of karstified limestone with geotourism potential, established as Karst Landscape Area. As basis for infrastructure development in geotourism area, a database of geosites need to be built to make sure it is available for government and public. The method used is field observation, interviews and SWOT analysis. Morphology of this area is divided into conical karst hills and the karst alluvium plains. The lithology of the research area are reef limestone, clastic limestone, and alluvial deposit. Inventory managed to identify potential geosites such as hills, cliffs, caves, and springs; five existing geosites have been developed and six locations are new geosite recommendations. From the SWOT analysis, it is known that this location has the strength that is the uniqueness of morphology from karstification results, the weakness is geotourism concept is still not yet understood by local residents, the opportunity is the minister's decision regarding the Sukolilo Karst Landscape Area and the threat is lack of geological protection at the research site. The geotourism and geotrack map will serve as geospatial information and further recommendation for government to prioritize the infrastructure development in this area.
\end{abstract}

Keywords: geotourism information; karst geomorphology; Sukolilo karst; SWOT analysis.

\section{Introduction}

Geodiversity is considered as an important heritage and must be preserved for its history of lives. As a part of core elements in World Heritage aside from biodiversity, many worldwide national parks are situated within a certain geological condition. New opportunities in geotourism are motivated by connecting geological sites with natural and cultural elements $[1,2]$.

Geotourism as an alternative form in the field of tourism that can be an attraction for the appreciation of the objects of earth and its environment. In geotourism, several activities can be done such as geosite sightseeing, geosport, geostudy, geoconservation, geofestival, health and wellness geotourism. Geosite is a site that has geological meaning and importance of landforms, rock outcrops, fossils, minerals and other things related to geological phenomena [3]. Geotourism can also focus on cultural and historical aspects such as archaeological site, ex-mining site, or ancient buildings in particular geosite.

Indonesia has countless natural wonders as geotourism potential with many of these already certified by UNESCO and attracted visitors all over the world [2]. One of the significant geological features is karst landscape resulted from the dissolution process. Indonesia has broad variability in karst morphology producing scenic areas that able to attract visitors. The study area, Kayen District, is part of Sukolilo Karst as established by the government [4].
As a sustainable industry, geotourism gives many opportunities for local government and people. Socioeconomic gain must generate a positive impact with minimum damages. Better infrastructure is one of the tourist attractiveness element, so these benefits will likely be a reason for infrastructure to be developed in potential areas. This development will need a reliable database about the spatial distribution and the intrinsic values of each geosites. The database will be transferred into accessible information for the government and visitors [3].

This study aims to determine the geological conditions at the geosite location that have the potential to be developed, SWOT analysis, as well as the initial design of geosites that can be further developed. The research was conducted on karst hills in Kayen District, Pati Regency, Central Java. This location is limited by an area of $6 \times 6 \mathrm{~km}$ which includes Tompegunung Village, Durensawit Village, Beketel Village, Jimbaran Village, Sumbersari Village, Kedungmulyo Village, Cengkalsewu Village and Slungkep Village in the eastern part of Central Java with coordinates 495000$501000 \mathrm{mT}$ and $9230000-9236000 \mathrm{mU}$ (Fig. 1). The research location can be reached by motorized vehicles as far as $108 \mathrm{~km}$ for 2 hours 30 minutes via the Pantura route and as far as $91 \mathrm{~km}$ for 2 hours 30 minutes via the Purwodadi route from Semarang City.

* Corresponding author: triwingeo@gmail.com 


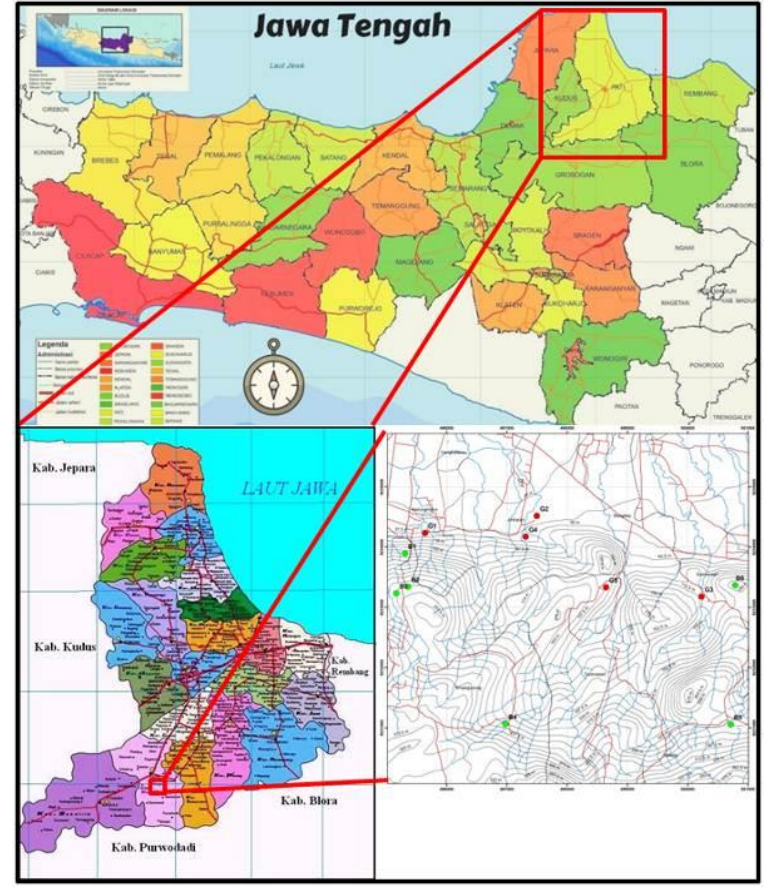

Fig. 1. Study area location [5]

\section{Geological Setting of Study Area}

Sukolilo Karst is a karstic mountain area located in the Rembang Zone [6]. It lies among three regencies; Pati, Grobogan, and Blora Regency. This area is specifically established as a national conservation area, with every spatial planning and activity must be under the local government's authority [5].

The geological setting of Sukolilo Karst is part of the Northeast Java Basin as a result of Tertiary sedimentation [7]. Details of the northern East Java Basin stratigraphy from the Rembang Zone are divided into several units namely Kujung Formation, Prupuh Formation, Tuban Formation, Tawun Formation, Ngrayong Formation, Bulu Formation, Wonocolo Formation, Ledok Formation, Mundu Formation, Selorejo Members, Paciran Formation, Lidah Formation, and Terrace Deposit (Fig. 2).

There are two main formations that developed Sukolilo Karst, mostly dominated by carbonate rocks. Tawun Formation consists of limestone and claystone, interbedded with sandstone, siltstone, and calcarenite. Ngrayong Member can be found in the upper part of Tawun, which characterized by sandstone, quartz sandstone, and lignite interbeds. The age of this formation is Lower-Middle Miocene, deposited at the shallow shelf to sublittoral and lagoon. Tawun Formation is overlaid conformably by clastic-reefal limestone of Bulu Formation. It consists of fossiliferous limestone with foraminifera, algae, bryozoan, and echinoid; interbedded with thin claystone and calcarenite. This thick succession is the Middle Miocene age.

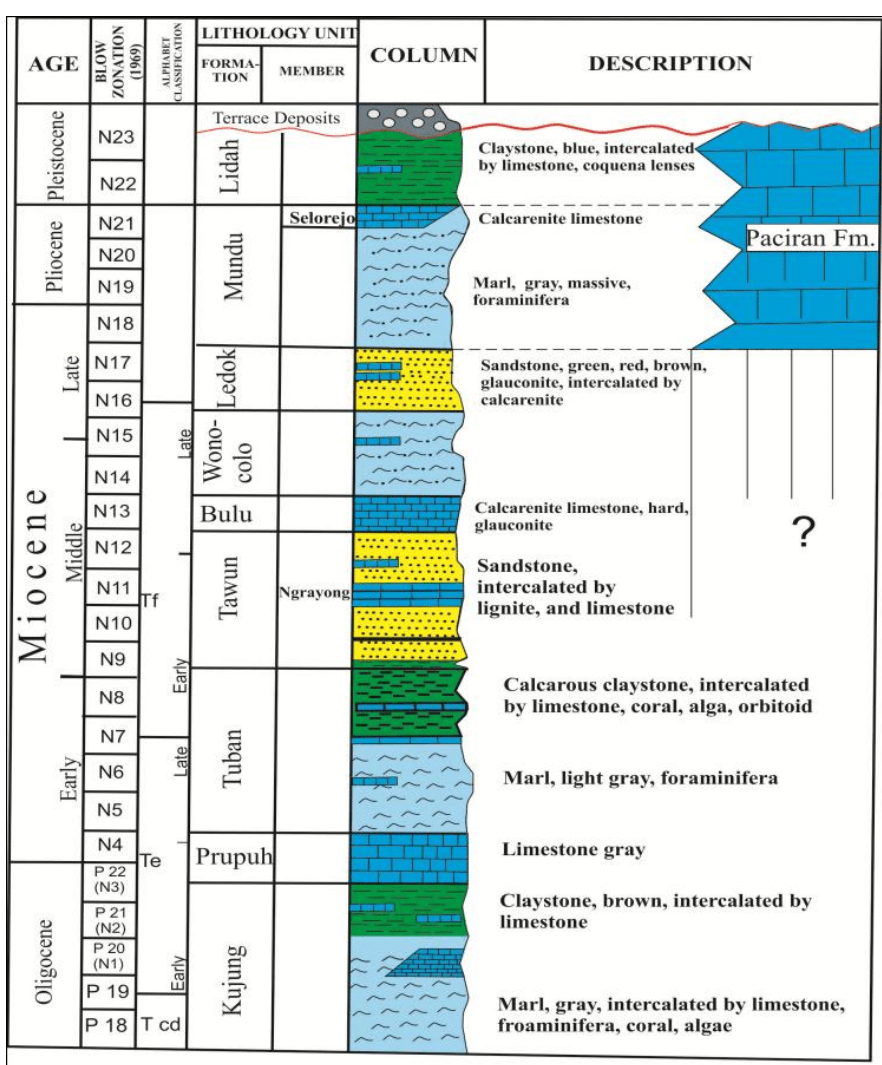

Fig. 2. Stratigraphy of Northeast Java Basin [7]. Study area is part of Tawun Formation, Ngrayong Member, and Bulu Formation

\section{Geotourism Objectives and Benefits}

Geotourism is special interest tourism by utilizing all the potential of natural resources so that it requires insight and understanding of the processes of natural physical phenomena $[8,9]$. Prospective visitors will set a standard of didactic and aesthetic. To meet this expectation, geosites must be developed based on their value and maintained sustainably [10].

\subsection{Geotourism Principles}

There are several things that need to be considered in the development of geotourism, including:
a. Geological based
b. Sustainable
c. Geologically informative
d. Locally beneficial
e. Tourist satisfaction

\subsection{Geotourism Objectives}

The objectives of geotourism are as follows:

a. Protecting the geological heritages from environmental damage and human activity.

b. Educating people not to damage the geological and historical sites, such as illegal digging of ancient artifacts or illegal rock mining.

c. Conducting geological diversity conservation activities including the conservation of flora and 
fauna in some places potential as a field laboratory and study center.

d. Socialize natural science, environmental education, and nature conservation.

e. Introduce new insights and knowledge about geological aspects such as fossils, rocks, landscapes, as well as cultural and historical aspects.

\subsection{Geotourism Benefits}

The benefits of geotourism are as follows:

a. Improve the welfare of the people who live around them with the development of jobs and entrepreneurship for the local community.

b. Encourage the surrounding community to participate in maintaining and developing the object of geotourism.

c. Create sustainable tourism development and based on local wisdom.

d. Encourage visitors to appreciate the location of the geotourism object by geological aspect.

e. Give particular impressions and experiences that are different from other tourist activities.

\section{Methodology}

\subsection{Field Data Collecting}

Field investigations have been conducted to understand the geological aspects of the study area. The occurrence of unique features must correspond with geomorphology and stratigraphy. Field geological mapping documented characteristics of morphology, lithology identification, and description. Inventory of geosite has been undertaken with close identification, field description, and documentation as well as collected secondary information related to the study area. Each geosite is also identified for its uniqueness, initial infrastructure, and accessibility. The interview has been conducted to gather information about cultural, biological, and social aspects. It is provided by the local government, residents, and tourists.

\subsection{SWOT Analysis}

SWOT (Strength, Weakness, Opportunity, and Threat) analysis is a strategic plan used to evaluate strengths, weaknesses, opportunities, and threats (Table 1). The determination of the SWOT analysis is based on qualitative assessment. SWOT analysis in a geosite area is carried out by considering geological conditions, management structures, environmental education, and regional economic development.

This SWOT assessment takes into account internal and external factors as follows:

a. Strength: This analysis will look at any conditions or situations that are considered as a force to increase market segmentation. At this stage, it must be able to analyze its strength or superiority to be the main attraction. This superiority or strength can also be used to fulfill market segmentation in need.

b. Weakness: This is interpreted as an analysis of any condition or situation that is a weakness. This weakness may be an obstacle that impedes development

c. Opportunities: This component also includes the search for possibilities or opportunities and innovations that will provide opportunities to continue to develop in the future.

d. Threats: This means to analyze each condition or situation that could be a threat or even a challenge that must and will be faced in carrying out and developing something. The purpose of this threat analysis is to be able to find a solution to overcome this threat.

Table 1. SWOT analysis diagram

\begin{tabular}{|c|c|c|}
\hline $\begin{array}{r}\text { External } \\
\text { Factor }\end{array}$ & Opportunity (O) & Threat (T) \\
Factor & & \\
\hline Strength (S) & Strategic Plan (SO) & $\begin{array}{c}\text { Strategic Plan } \\
\text { (ST) }\end{array}$ \\
\hline Weakness (W) & $\begin{array}{c}\text { Strategic Plan } \\
\text { (WO) }\end{array}$ & $\begin{array}{c}\text { Strategic Plan } \\
\text { (WT) }\end{array}$ \\
\hline
\end{tabular}

After discovering the strengths, weaknesses, opportunities, and threats that exist then the strategic plan is made as follows:

a. Strengths - Opportunities (SO): Use existing strengths to create opportunities.

b. Strengths - Threats (ST): Use strengths to avoid and eliminate threats.

c. Weaknesses - Opportunities (WO): Eliminate existing weaknesses to create opportunities.

d. Weaknesses - Threats (WT): Eliminate weaknesses to avoid threats

\section{Results and Discussion}

The geological conditions of the study area were obtained from the results of the mapping carried out on an area of $6 \times 6 \mathrm{~km}$. In this mapping, the geomorphological and stratigraphic conditions were observed.

\subsection{Geomorphology}

Based on morphometry and morphogenetic aspects, the study area can be divided into two topographic units (Fig.3). First, conical karst hills are the dominant unit, distinguished by rolling topography and featured numerous karst cones, caves, and waterfalls. It covered $70 \%$ of the study area with a slope of $8-20 \%$. This terrain results from dissolution and erosion of limestone formation commonly in a tropical region. The other terrain is karst alluvial plain with gently undulating slope 
3-7\%. Denudational and sedimentation are dominant processes in this area, resulting in alluvial lithology.

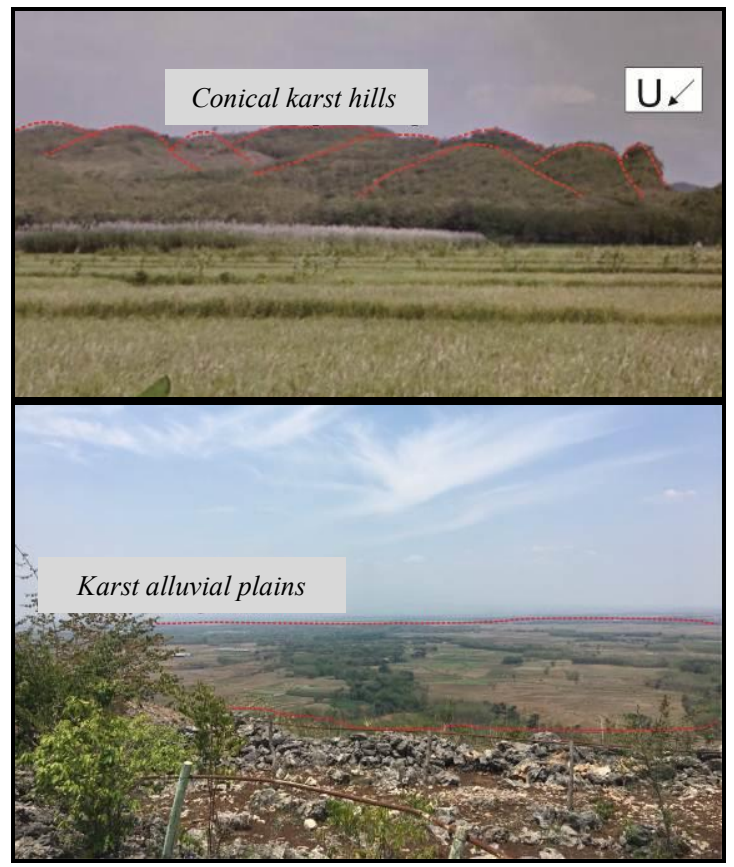

Fig. 3. Morphology of the study area, show distinctive karst features

\subsection{Stratigraphy}

Based on geological mapping, there are three lithological units i.e. clastic limestone, reef limestone, and alluvial deposit (Fig.4).

\subsubsection{Clastic Limestone}

This unit characterized by yellowish color, medium grain size, good sorting, and bedding with strike/dip $265^{\circ} \mathrm{E} / 42^{\circ}$. It is composed of the coral fragment and foraminifera fossils, packed together by carbonaceous grains and cement. Clastic limestone can be found in the southwest part of the study area.

\subsubsection{Reef Limestone}

The most dominant lithological unit is reef limestone, characterized by yellowish white color and no apparent bedding or massive structure. It is composed by larger and angular carbonate fragments, algae, coral fragments, and larger foraminifera, which are packed together by carbonate cement.

\subsubsection{Alluvial Deposit}

Alluvial deposit is materials resulting from denudational processes such as erosion, transportation, and sedimentation of existing rocks from higher conical karst hills morphology. This deposit covers the northern part of the study area, characterized by brown color, loose, and fine grained materials.

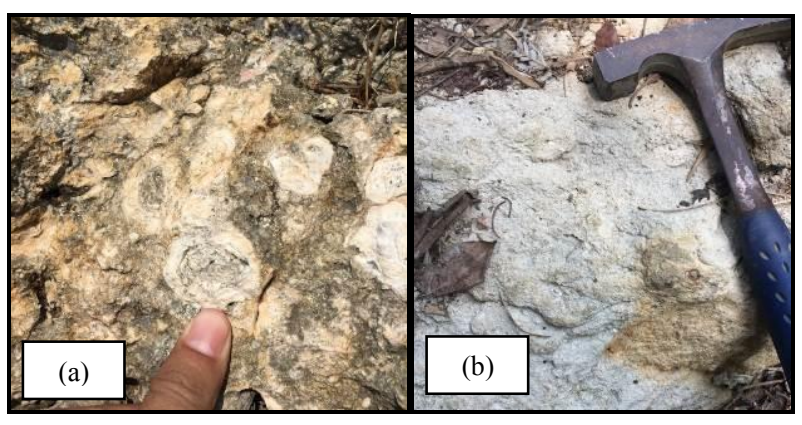

Fig.4. Limestone as main lithology of the study area : (a) reef limestone with algae and coral fragments, (b) clastic limestone

\subsection{Geosites in Karst Area}

As part of Sukolilo Karst, this area has been protected legally [4], considers that the karst landscape has a unique geological component and serves as a natural drainage system. The inventory of geosites comprises of existing geosites (G1 - G5) and new geosites recommendation $(\mathrm{B} 1-\mathrm{B} 6)$.

\subsubsection{Wareh Cave (G1)}

Wareh Cave is located in Kedungmulyo Village, Sukolilo District. It is managed by local residents and has not been much assisted by the government. Tourist support facilities that have been available at this location are food stalls, gazebos for rest and relaxation, public toilets, prayer rooms, spacious parking spaces, information boards and selfie spot at the top of the cave. The main cave's mouth from Gua Wareh facing north has a quite large opening around $5 \times 3 \mathrm{~m}$. The second mouth of the cave faces west and is a dry cave, formed due to debris that occurs in the upper wall of the cave with opening about $2 \times 2 \mathrm{~m}$ or commonly called the cave window (Fig. 5a).

\subsubsection{Pancur Cave (G2)}

Pancur Cave is located in Jimbaran Village, Kayen District. The location of this cave has been well managed by the community and the local government. Some facilities such as parking lots, outbound areas, prayer rooms, and so on. The mouth of Pancur Cave has a width of about $3 \mathrm{~m}$ and a height of $2 \mathrm{~m}$. Inside the mouth of the cave, there is a spacious room before entering the next cave's mouth which is smaller or called the travertine terrace. This cave shows the subsurface river system which then flows to the surfaces and has stalactitestalagmite features (Fig.5b). 

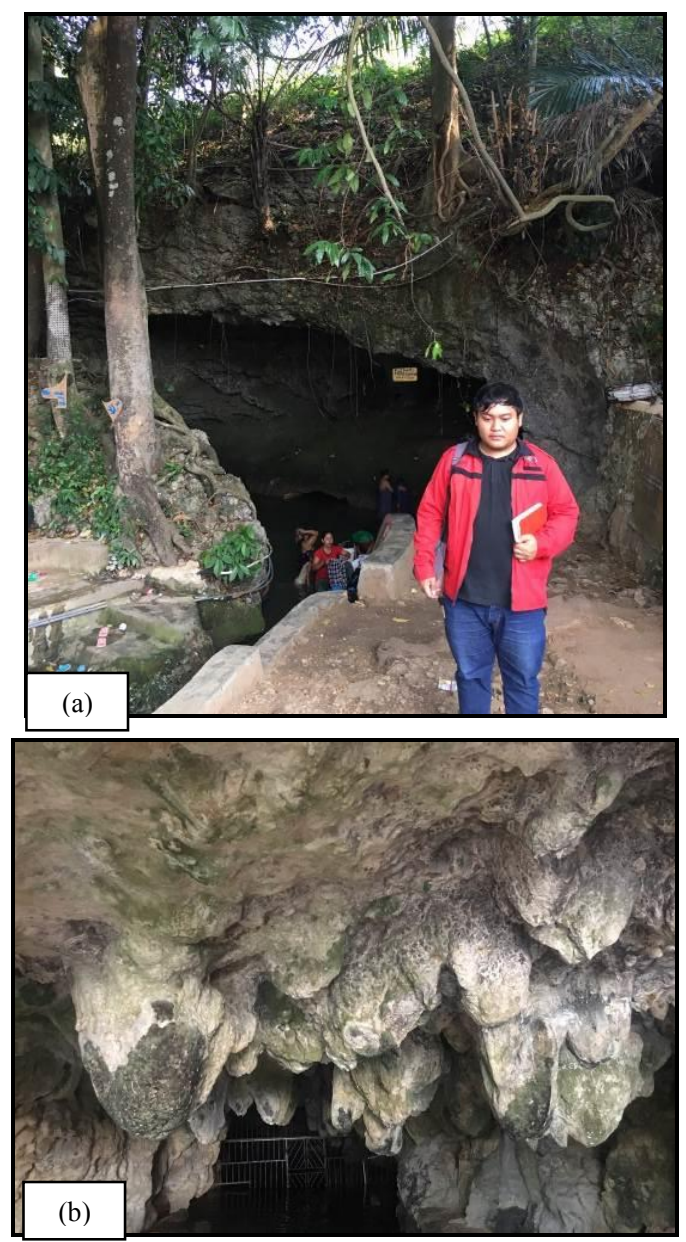

Fig. 5. Existing geosites featuring limestone cave, (a) Wareh Cave, (b) Pancur Cave

\subsubsection{Sumber Ndodo Spring (G3)}

Sumber Ndodo Springs is located in Jimbaran Village, Kayen District. This spring is part of a karst groundwater system, which travels through cracks or fissures, so the water eventually emerges from the subsurface. It became a historical place for the local ancestor, Ki Ageng Simbar Joyo Kusumo, which attracts local residents or tourists to visit this location. The Sumber Ndodo Springs has not been well managed by the local government (Fig. 6 ). Therefore, the role of local residents is very much needed to develop this Sumber Ndodo Springs tourism. Facilities currently available such as food stalls, parking lots, and resting places are still inadequate.

\subsubsection{Ki Santa Mulya Hill (G4)}

Ki Santa Mulya Hill is located in Durensawit Village, Kayen District (Fig. 7). From the top of the hill to the north you will see the plain landscape of Pati Regency and to the south, you will see a landscape in the form of a conical karst zone. Facilities that have been available at this location include a payer room, public toilets, food stalls, resting area, open meeting rooms at the top of the hill, a spot for selfie, and also a large parking area even enough to accommodate large tourist buses. A more intensive dissolution process produced the appearance of cone-shaped hills. The karst cone hill is characterized by its cone shape, has a fairly steep slope and is surrounded by depression.

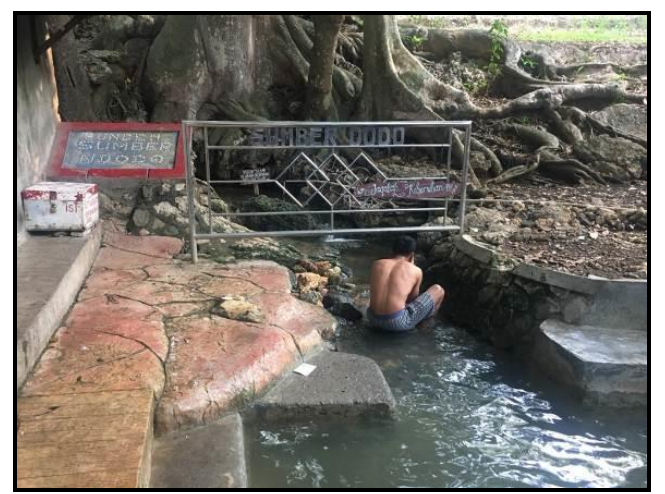

Fig. 6. Sumber Ndodo spring with great discharge

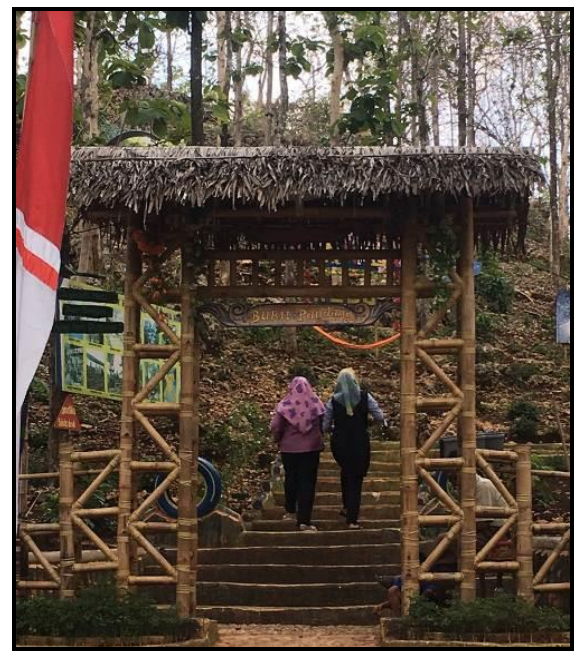

Fig. 7. Entrance of Ki Santa Mulya Hill

\subsubsection{Lorotan Semar Waterfall (G5)}

Lorotan Semar Waterfall is located in Ngalingan, Sumbersari Village, Kayen District. It has been well managed by local residents and the government, various tourism support facilities have been built in this location such as public toilets, food stalls, resting places, and parking lots. It was formed by intensive dissolution along with the fractures and faults for a long time it becomes wider and deeper. This geosite is suitable for geosport, sightseeing, study, and cultural tourism. Geofestivals or events related to the sustainability of geological resources promotes conservation programs. The population of long tailed macaques (Macaca fascicularis) were found to add biodiversity value (Fig.8). 


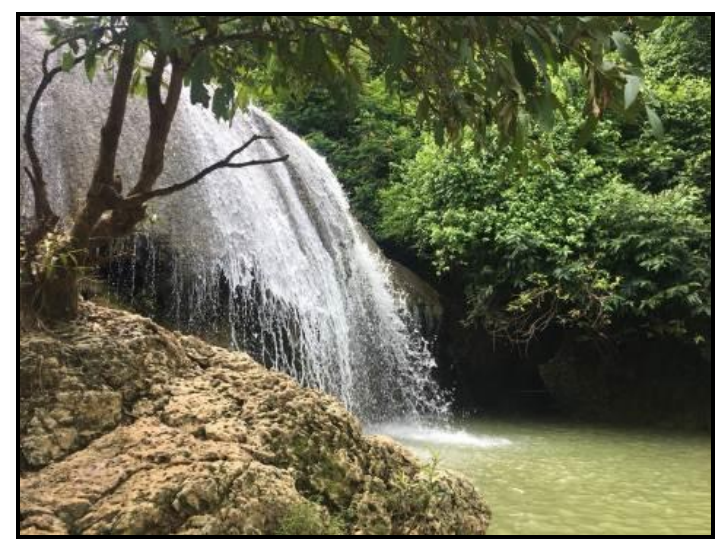

Fig. 8. Three step of Lorotan Semar Waterfall

\subsubsection{Tompegunung Cliff (B1)}

Tompegunung Cliff is located in Tompegunung Village, Sukolilo District. The uniqueness of this location is two facing high cliffs that flank the road to form a hallway. This fascinating rock exposure has been formed from a fairly intensive dissolution process in a very long time so that the fracture gets wider and deeper (Fig.9). It is suitable for geosport activity includes rappelling and wall climbing. At the top of the cliff, a wonderful view of the surrounding plains will be a good sightseeing spot. Tompegunung Cliff is yet to be managed by local residents or government.

\subsubsection{Tompegunung Cave (B2)}

Tompegunung Cave is located in Tompegunung Village, Sukolilo District. It develops karstic features such as small stalactite and stalagmite which potential to grow more in the future. Tompegunung is a dry cave because there are no springs or subsurface river systems. Tompegunung Cave has not been used by local residents as a tourist spot. The access and open area to build facilities are narrow and limited.

\subsubsection{Tompegunung Hill (B3)}

It is a $225 \mathrm{~m}$ height karstic cone located near Tompegunung Cave. The geotourism activities that can be done on the Bukit Pandang Tompegunung are geosite sightseeing or enjoying the beauty and uniqueness of the earthly landscape. Geosite sightseeing also includes observations of morphology, unique rock types, and so on. In addition, geosport can also be done by exploring the karst cone hill. This geosite has not been used by local residents as a tourist spot. This hill area is wide enough to build public tourism support facilities such as eating places, prayer rooms, toilets, security posts and even parking lots in the future. This study proposed geosite design for this geosite and nearby (Fig. 10).

\subsubsection{Tompegunung Spring (B4)}

Located in Tompegunung Village, Sukolilo District, this spring is a fissure or fracture spring. Water from this spring is clear and can be used for local residents. Tourists can relax here and enjoy the landscape as this geosite is suitable for health and wellness geotourism.
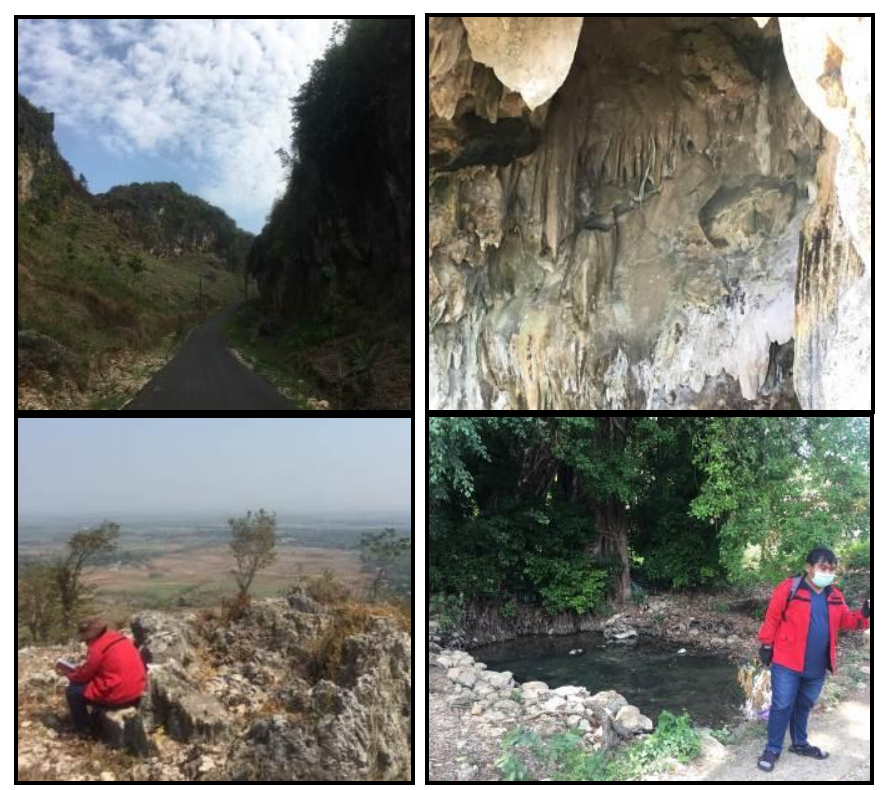

Fig. 9. Geosites at Tompegunung with various morphology. From upper left clockwise: cliff, stalagmite cave, spring, and hill top

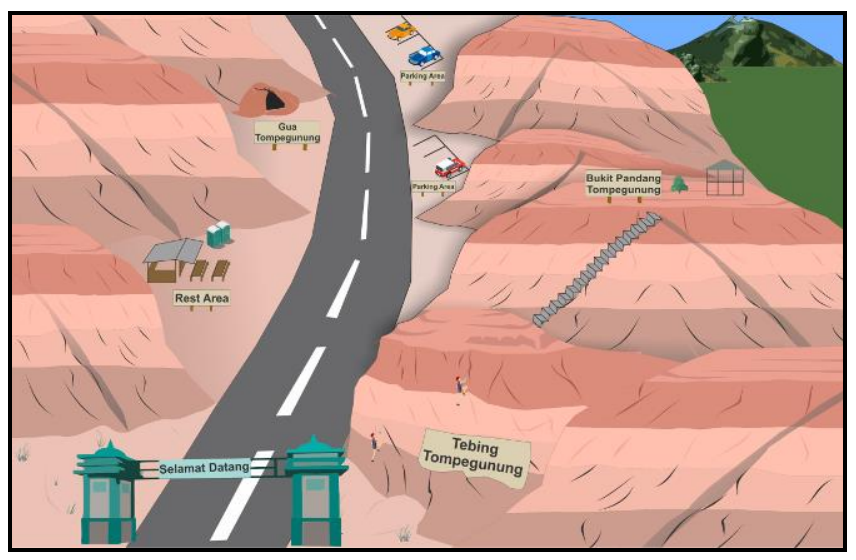

Fig. 10. Proposed geosite design for Tompegunung area (Tompegunung Cliff, Tompegunung Hill, and Tompegunung Cave)

\subsubsection{Tepus Lake (B5)}

Tepus Lake is located in Kebun, Beketel Village, Kayen District and managed by the Central Java Marine and Fisheries Service as a rehabilitation activity for vital habitats. Many people are fishing illegally here. Lake Tepus is a depression formed due to the surrounding karst hills and then filled with surface water. The water in this lake comes from rainwater and river flow. During the dry season, the lake has an area of about 50x40 m. Besides sightseeing and geological observation, this site also potential for geo-conservation. 


\subsubsection{Kandangan Hill (B6)}

Kandangan Hill is located in Ngalingan, Sumbersari Village, Kayen District. Kandangan Hill is one of the hills that belongs to the conical karst hill morphology. Geotourism activities that can be done in Kandangan Hill are geosite sightseeing and also includes observations of morphology, unique rock types, and so on. In the north, there is a plain landscape of Pati Regency, while the southern part is seen as karst hilly landscape. In addition, geosport can also be done by exploring the karst cone hill. The proposed geosite design is in Fig.12.
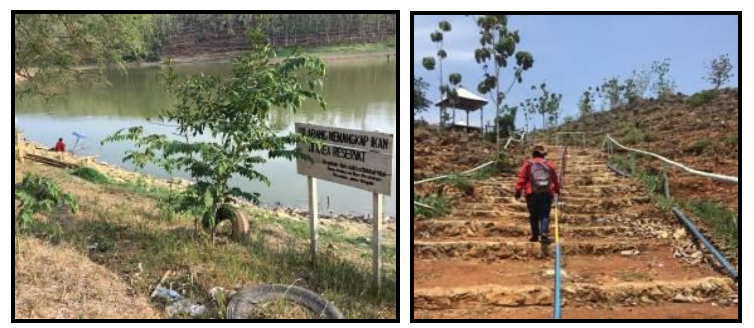

Fig. 11. Tepus Lake with prohibition for illegal fishing (a), and Kandangan Hill (b)

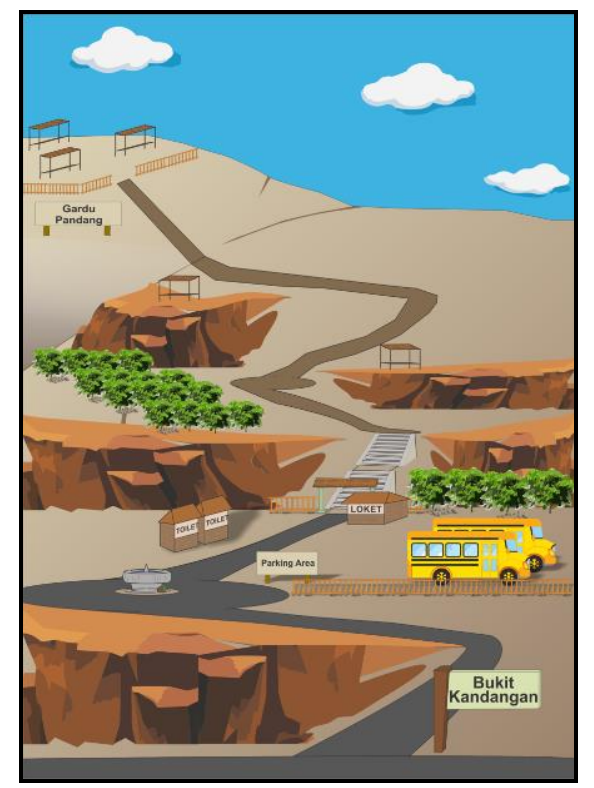

Fig. 12. Proposed geosite design for Kandangan Hill (Bukit Kandangan)

\section{4 Biodiversity and Cultural Diversity}

Biodiversity data in the study area was obtained from the results of interviews and material from the local tourism agency. The diversity of flora in this area includes kalumpit trees (Terminalia microcarpa) and kapok trees (Ceiba pentandra). While fauna includes green peacocks (Pavo sp.), long-tailed macaques (Macaca fascicularis) and crested serpent eagles (Spilornis cheela). The cultural rite that still survives is the Meron Ceremony, which is a traditional custom for village officials to which requires taking part in ceremonies. It is held every year, coincident with the celebration of Prophet Muhammad's birthday.

\subsection{SWOT Analysis}

The research location has strength in the form of abundant tourist attractions ranging from those that have been developed to those that have the potential to be developed. The tourist location has aesthetic and scientific value in the field of geology and the support of the surrounding community such as participating in managing tourist sites, providing land for tourist location support facilities, maintaining and caring for the naturalness of geosite and available facilities. Weakness is the concept of geotourism that is not yet known to the surrounding community so that its development is less focused on its geological uniqueness, some locations lack the natural geology, the absence of professional tour guides in the field of geotourism and lack of tourism promotion in this area.

Opportunities are the existence of support from the government in the form of ministerial decree No. $2641 \mathrm{~K}$ / 40 / MEM / 2014 (Fig.13), the research location has a fairly high aesthetic value so it is very supportive in the digital era that prioritizes the aesthetics of tourist sites. Costwise, it is a very affordable tourism site that can be entered for free. Whereas the threat is the lack of geological protection efforts because of the community's need for other things so that the existing geological resources are not properly maintained.

\subsection{Geotourism and Geotrack Map}

On the geotourism and geotrack map, eleven geosite locations have the potential to be developed. The red dots indicate the location of the geosite that has been developed as a tourist location, while the blue dots are the recommended geosite location to be developed.

This study proposed two different track which can be reached within a day per track. The selection of this track is adjusted to the conditions of road access (quite smooth and wide so that it makes it easier for tourists to use four-wheeled vehicles or more and do not have many intersections so as not to confuse tourists). The order of the geosite location that is targeted is also based on the closest distance from the previous geosite for easy access.

\section{Conclusion}

Database and information related to geosites inventory have been done by geological mapping, interviews, and SWOT analysis have been done. The geomorphology of the study area consists of conical karst hills and alluvial karst plains. There are three different lithologies, namely clastic limestone, reef limestone, and alluvial deposit. Limestones mostly from Bulu Formation which plays a role in the formation of karst morphology. This study found five geological sites that have been developed as geotourism locations, namely Pancur Cave, Sumber Ndodo Spring, Wareh Cave, Ki Santa Mulya Hill, and Lorotan Semar Waterfall. 


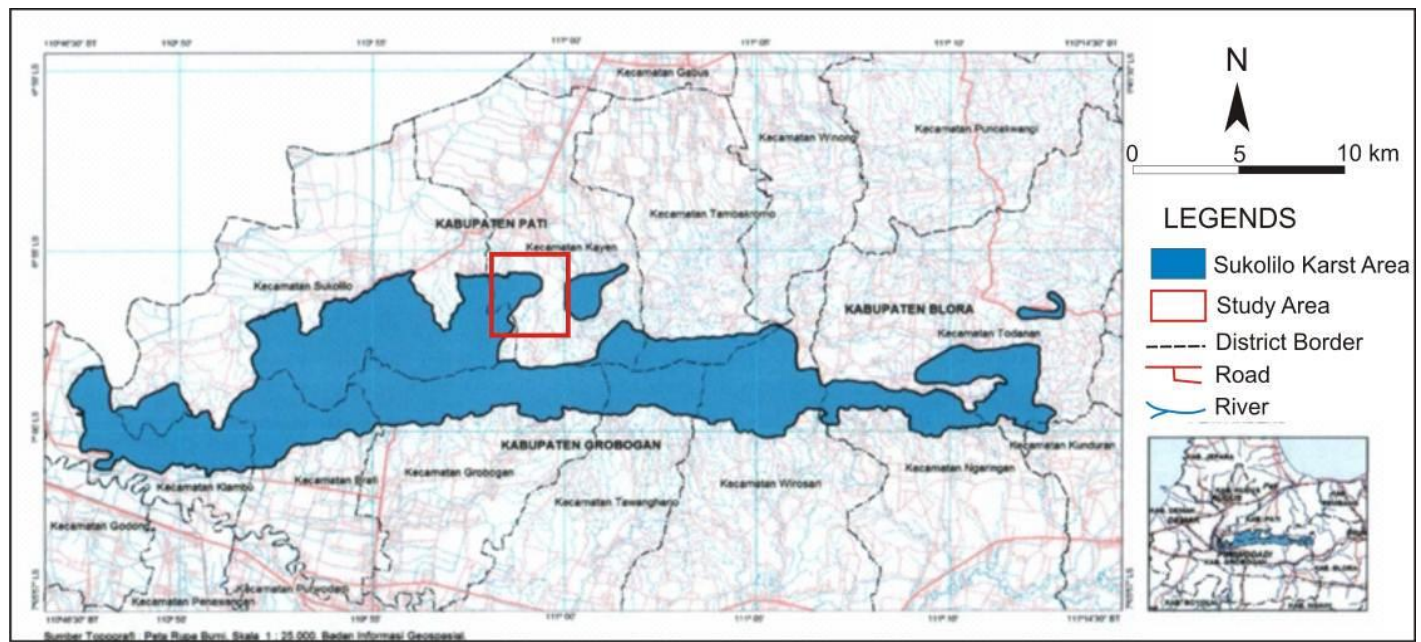

Fig. 13. Legacy of study area as part of Sukolilo Karst Area which is an opportunity to develop geotourism [4]

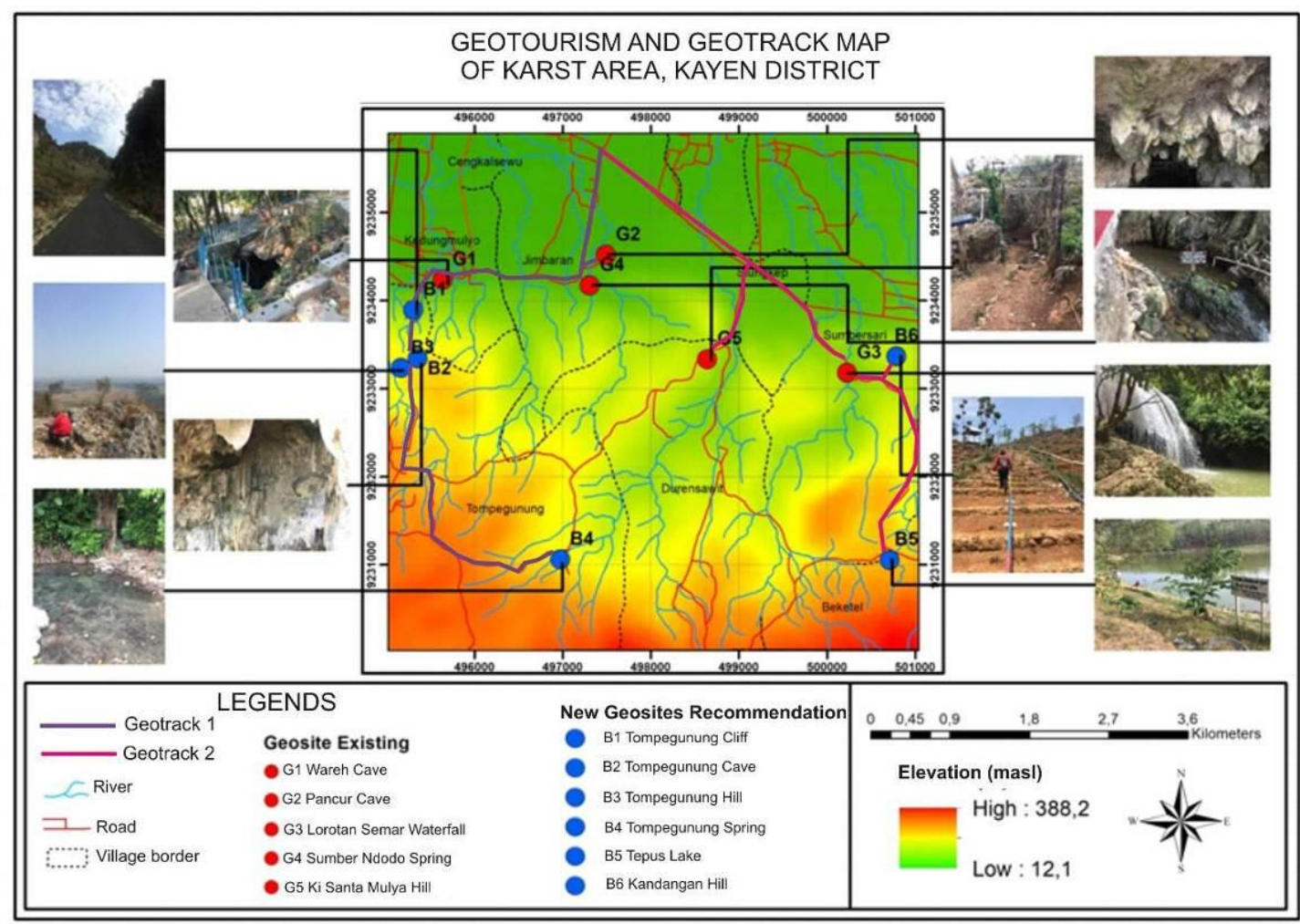

Fig. 14. Geotourism and geotrack map of Karst Area, Kayen District, Pati Regency

In addition six geological sites are recommended to be developed to tourism sites namely Tompegunung Cliff, Tompegunung Cave, Tompegunung Hill, Tompegunung Spring, Kandangan Hill, and Tepus Lake. There are distinctive flora and fauna in this region including kalumpit plants, kapok plants, crested serpent eagles, green peacocks, and long-tailed macaques. From the SWOT analysis, it is known that this location has the strength that is the uniqueness of morphology from karstification results, the weakness is geotourism concept is still not yet understood by local residents, the opportunity is the minister's decision regarding the Sukolilo Karst Landscape Area and the threat is lack of geological protection at the research site. The geotourism and geotrack map will serve as geospatial information and further recommendation for the government to prioritize the infrastructure development in this area. 


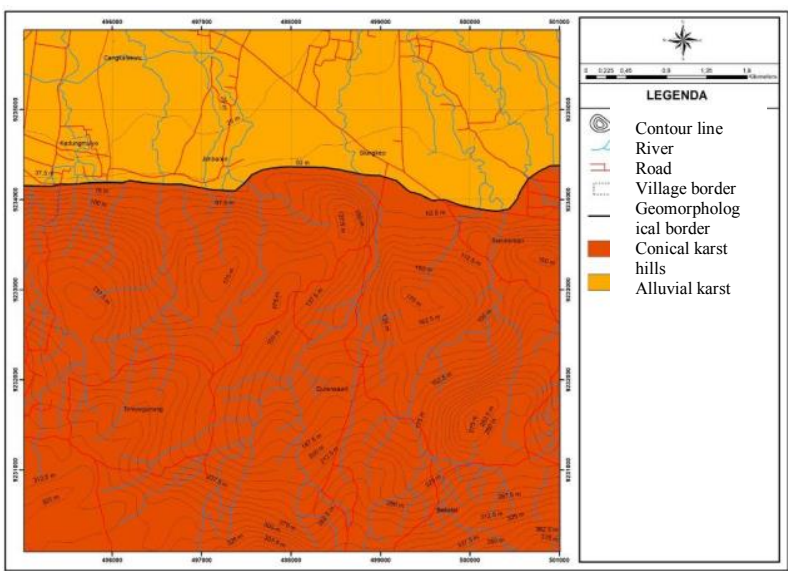

Fig. 15. Geomorphological map of study area

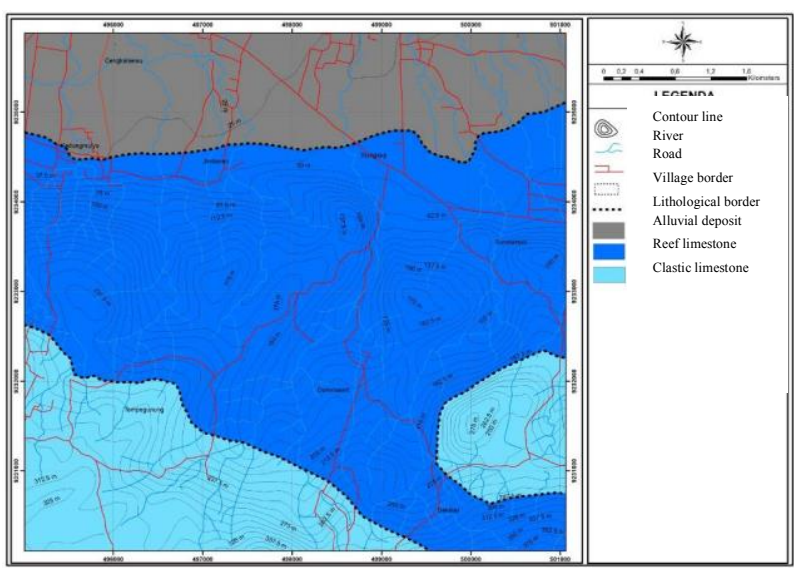

Fig. 16. Geological map of study area

\section{Acknowledgement}

The author would like to thank Mr. Krisno, supervisor of tourism development at Kayen District from Pati Regency Tourism for valuable information related to biodiversity and cultural diversity of the study area.

\section{References}

1. Y.K. Koh, K.H. Oh, S.T. Youn, H.G. Kim, J. Mar. Isl. Cult. 3, (2014)

2. UNESCO, Global Geoparks available from : http://www.unesco.org/new/en/naturalsciences/environment/earth-sciences/unesco-globalgeoparks/ (2019)

3. R.K. Dowling, Geotourism, 3 (2011)

4. Ministry of Energy and Mineral Resources, Ministerial Decree No. 2641K/40/MEM/2014 about Karst Sukolilo Protection (2014)

5. Pattiro, Central Java Map, available from http://soloraya.net/migas-era-gubernur-baru/petajawa-tengah/ (2013)

6. R.W. van Bemmelen, The Geology of Indonesia: General Geology of Indonesia and Adjacent Archipelagoes, The Hague IA (1970)

7. H. Pringgoprawiro, Biostratigraphy and Paleogeography of North East Java Basin: A New Approach, Disertasi Doktor ITB (1983)

8. R. Nainggolan, J. Pen. Pend. Sos. Hum 1 (2016)

9. A. Chen, Y. Lu, Y. Ng, Principle of Geotourism, Science Press Beijing (2015)

10. K. Widawski, Z. Jary, P. Olesniewicz, P. Owczarek, J. Markiewicz-Patkowksa, A. Zareba, Open Geoscience 10 (2018) 